\title{
Pengembangan Sistem Kuis Algoritma Pemrograman Berbasis Web
}

\author{
Novian Dwi Syahrizal Hilmi, Harits Ar Rosyid \\ Universitas Negeri Malang, Jl. Semarang No.5 Kota Malang 65145, Indonesia
}

\begin{tabular}{|c|c|}
\hline INFO ARTIKEL & ABSTRAK \\
\hline Riwayat Artikel: & Abstract: This study aims to: design and develop a web-based \\
\hline Diterima: $24-10-2020$ & programming algorithm quiz system and determine the validity of the web- \\
\hline Disetujui: 11-11-2020 & observations on students, facts were found that showed problems in \\
\hline Kata kunci: & $\begin{array}{l}\text { obtained by distributing questionnaires to students. From this information, } \\
\text { it is found that the algorithm is the most important programming material. }\end{array}$ \\
\hline Kuis & The results showed that the feasibility assessment of the programming \\
\hline Algoritma pemrograman & $\begin{array}{l}\text { algorithm quiz system by media experts obtained data of } 85.71 \% \text { on the } \\
\text { usage aspect, } 85 \% \text { on the design aspect, and } 85 \% \text { on the function aspect. }\end{array}$ \\
\hline Flowchart & $\begin{array}{l}\text { With an average data acquisition of } 85.29 \% \text {. From these results, it can be } \\
\text { concluded that the programming algorithm quiz system that has been } \\
\text { developed is suitable for use with minor revisions. }\end{array}$ \\
\hline & $\begin{array}{l}\text { Abstrak: Penelitian ini bertujuan untuk merancang dan mengembangkan } \\
\text { sistem kuis algoritma pemrograman berbasis web dan mengetahui validitas } \\
\text { sistem kuis algoritma pemrograman berbasis web. Berdasarkan hasil } \\
\text { pengamatan pada mahasiswa, ditemukan fakta yang menunjukkan per- } \\
\text { masalahan pada pemahaman untuk menyelesaikan permasalahan dalam } \\
\text { pemrograman komputer. Informasi didapatkan dengan menyebarkan kuesi- } \\
\text { oner pada mahasiswa. Dari informasi tersebut, didapatkan data bahwa al- } \\
\text { goritma merupakan materi pada pemrograman yang paling penting. Hasil } \\
\text { penelitian menunjukkan, penilaian kelayakan sistem kuis algoritma pemro- } \\
\text { graman oleh ahli media mendapatkan perolehan data sebesar } 85,71 \% \text { pada } \\
\text { aspek penggunaan, } 85 \% \text { pada aspek desain, dan } 85 \% \text { pada aspek fungsi. } \\
\text { Dengan rata-rata perolehan data sebesar } 85,29 \% \text {. Dari hasil penelitian ter- } \\
\text { sebut maka dapat disimpulkan bahwa sistem kuis algoritma pemrograman } \\
\text { yang telah dikembangkan sudah layak digunakan dengan revisi kecil. }\end{array}$ \\
\hline
\end{tabular}

\section{Alamat Korespondensi:}

Harits Ar Rosyid

Fakultas Teknik

Universitas Negeri Malang

Jl. Semarang 5 Malang 65145 Jawa Timur Indonesia

E-mail: harits@ft.um.ac.id

\section{PENDAHULUAN}

Pembelajaran berbantuan komputer adalah segala sesuatu aktivitas pembelajaran yang dilakukan melalui komputer sebagai alat bantu pembelajaran, yang mencakup komputer sebagai alat bantu (tools) dan komputer sebagai tutor". Jadi pada saat kegiatan belajar dan mengajar, dengan menggunakan komputer sebagai bantuan pembelajaran dapat menari minat peserta didik dalam mengikuti pelajaran (Patmanthara, 2016).

Algoritma merupakan deretan urutan langkah-langkah untuk memperoleh hasil akhir yang diinginkan yang bertujuan untuk menyelesaikan permasalahan tertentu. Langkah-langkah tersebut akan diterjemahkan 
secara berurutan dari awal hingga akhir. Masalah yang akan diselesaikan algoritma dapat berbentuk apa saja, dengan syarat mempunyai kondisi awal dan kondisi akhir yang harus dipenuhi. Algoritma juga memiliki proses dan pengulangan untuk memenuhi kondisi akhir (Sembiring et al., 2018). Sementara itu, algoritma pemrograman merupakan langkah-langkah yang dituliskan berurutan untuk menyelesaikan permasalahan pada pemrograman komptuer (Sitorus, 2015).

Ada 3 hal dalam pertimbangan memilih algoritma, yaitu (1) algoritma harus benar. Yang berarti algoritma harus memberikan keluaran sesuai kehendak dari masukan yang diperoleh. Tidak peduli algoritma tersebut bagus, bukan algoritma yang baik jika memberikan keluaran yang salah, (2) seberapa baik hasil algoritma yang dicapai harus diperhatikan. Hasil yang sedekat mungkin dengan nilai yang sebenarnya penting dalam algoritma yang baik, (3) efisiensi algoritma. Meskipun algoritma memberikan keluaran yang benar, akan tetapi menunggu lama untuk mendapatkannya, algoritma tersebut merupakan algoritma buruk (Nasution, 2013).

Pada mata kuliah algoritma dan struktur data, telah dipelajari algoritma dan penerapannya dalam pemrograman komputer. Kesulitan yang dihadapi mahasiswa dalam permasalahan ini adalah susahnya untuk memahami algoritma dan penyelesaian dari permasalahan yang dihadapi, dan juga sulitnya membayangkan struktur data yang akan digunakan (Isroqmi, 2017). Dalam memahami penyelesaian permasalahan, mahasiswa akan lebih mudah mengingat dan memahaminya bila permasalahan itu dapat ditampilkan dalam bentuk visual seperti diagram alir (Trianto, 2010).

Diagram alir atau flow chart ialah langkah-langkah program mulai dari awal hingga akhir berupa garis alir dan simbol tertentu. Simbol tersebut mewakili fungsi-fungsi garis alir dan langkah program yang menunjukkan urutan dari simbol-simbol yang dikerjakan. Flowchart lebih baik digunakan dibandingkan pseudocode. Karena jumlah simbol dalam flowchart sedikit, sehingga membuat flowchart lebih mudah dipahami dan sederhana. Dengan belajar melalui flowchart atau bisa juga disebut gaya belajar visual, siswa dapat belajar melalui memandangi, melihat, mengamati, dan sebagainya (Nuraini, 2015). Lebih jelasnya, "gaya belajar visual adalah belajar dengan melihat sesuatu, baik melalui gambar atau diagram, pertunjukkan, peragaan atau video" (Ula, 2013).

Flowchart adalah bagan yang dibuat untuk merepresentasikan suatu prosedur kegiatan penyelesaian masalah atau suatu algoritma, pengunaan flowchart akan mempermudah untuk melakukan pengidentifikasian pada bagian yang bermasalah pada saat analisis masalah. Flowchart juga berfungsi sebagai media untuk mengetahui alur sebuah program, sehingga memudahkan saat mengembangkan sebuah program yang dikembangkan secara tim pada suatu proyek. Menurut (Santoso \& Nurmalina, 2017), "Flowchart membantu memahami urutan-urutan logika yang rumit dan panjang. Flowchart membantu mengkomunikasikan jalannya program ke orang lain (bukan pemrogram) akan lebih mudah”.

Berdasarkan hasil pengamatan pada mahasiswa, ditemukan fakta yang menunjukkan permasalahan pada pemahaman untuk menyelesaikan permasalahan dalam pemrograman komputer. Informasi didapatkan dengan menyebarkan kuesioner pada mahasiswa. Dari informasi tersebut, didapatkan data bahwa algoritma merupakan materi pada pemrograman yang paling penting (Sismoro, 2005). Dan dengan mempelajari algoritma menggunakan flowchart dapat memudahkan untuk lebih memahami algoritma (Sukarsa, 2019).

Dengan memperhatikan kebutuhan mahasiswa dalam mempermudah memahami dan mempelajari algoritma pemrograman, maka peneliti menemukan gagasan dan tertarik untuk melakukan penelitian dengan judul "Pengembangan Sistem Kuis Algoritma Pemrograman Berbasis Web di Jurusan Teknik Elektro Universitas Negeri Malang". Berdasarkan latar belakang tersebut, penelitian ini bertujuan untuk: merancang dan mengembangkan sistem kuis algoritma pemrograman berbasis web dan mengetahui validitas sistem kuis algoritma pemrograman berbasis web.

\section{METODE}

Pada penelitian ini, peneliti menggunakan model pengembangan 4D sebagai dasar dalam melakukan pengembangan sistem kuis untuk algoritma pemrograman. Model penelitian dan pengembangan 4D terdiri atas 4 tahap yaitu define, design, develop, dan disseminate. Menurut (Trianto, 2010), "Model penelitian dan pengembangan 4D dapat diadaptasikan menjadi $4 \mathrm{P}$ yaitu: pendefinisian, perancangan, pengembangan, dan penyebaran (Wijayanti \& Sungkono, 2017). Penerapan langkah utama dalam penelitan tidak hanya menurut 
versi asli namun disesuaikan dengan karakteristik subjek dan tempat asal" [4]. Secara rinci alur pengembangan yang akan diterapkan seperti terlihat pada Gambar 1.

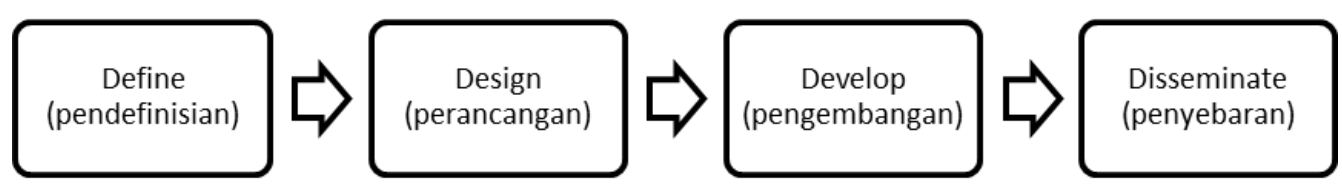

Gambar 1. Alur model pengembangan 4D

Dalam proses pengembangan sistem kuis ini dilakukan prosedur atau tahapan yang sesuai dengan model yang telah peneliti pilih yaitu model pengembangan 4D. Peneliti memilih model pengembangan 4D pada penelitian ini karena lebih jelas langkah pada setiap tahap pengembangannya. Pada model pengembangan 4D, tidak dicantumkan tahap implementasi dan evaluasi dikarenakan pada proses development selalu menyertakan implementasi dan evaluasi. Tidak seperti model pengembangan lain seperti model pengembangan ADDIE, yang dimana setelah tahapan development masih ada tahap selanjutnya yaitu tahap implementasi dan tahap evaluasi. Model pengembangan 4D menggunakan 4 tahap yang terdiri dari define (pendefinisian), design (perancangan), develop (pengembangan), dan dissemination (penyebaran) (Wijayanti \& Sungkono, 2017).

Untuk mengukur kelayakan media yang dikembangkan menggunakan angket validitas media (Tabel 1). Angket juga diberikan kepada ahli media untuk mengumpulkan data. Pada penelitian ini, peneliti menggunakan angket yang didalamnya berisi ratting scale yang merupakan angket didalamnya berisi pertanyaan dan kolom yang akan menunjukkan tingkatan-tingkatan (Purnomo, 2011). Jawaban angket dengan menggunakan angket Linkert dengan empat kategori pilihan sebagai berikut:

Nilai 4 : Sangat tepat / sangat sesuai / sangat lengkap / sangat baik

Nilai 3 : Tepat / sesuai / lengkap / baik

Nilai 2 : Kurang tepat / kurang sesuai / kurang lengkap / kurang baik

Nilai 1 : Tidak tepat / tidak sesuai / tidak lengkap / tidak baik

Teknik analisa yang digunakan untuk menganalisa kualitas data adalah berupa skor angket penilaian untuk ahli media dan dosen di Jurusan Teknik Elektro Universitas Negeri Malang. Rumus yang digunakan untuk mengolah data yang berupa deskriptif presentase adalah sebagai berikut:

Keterangan:

$$
V=\frac{T S E V}{S-\max } \times 100 \%
$$

V : Validitas

TSEV : Total skor empirik validitor

S-max : Skor maksimal yang diharapkan

Tabel 1. Kriteria Validitas Pengembangan Media

\begin{tabular}{cc}
\hline Kriteria & Tingkat validitas \\
\hline $75,01 \%-100,00 \%$ & Sangat valid (dapat digunakan tanpa revisi) \\
\hline $50,01 \%-75,00 \%$ & Cukup valid (dapat digunakan dengan revisi kecil) \\
\hline $25,01 \%-50,00 \%$ & Tidak valid (tidak dapat digunakan) \\
\hline $00,00 \%-25,00 \%$ & Sangat tidak valid (terlarang digunakan) \\
\hline
\end{tabular}

\section{HASIL}

Produk yang dihasilkan berupa website sistem kuis algoritma pemrograman. Website sistem kuis ini terdiri dari halaman masuk dan daftar, beranda dan kelas. Berikut adalah screenshot dari halaman-halaman yang ada pada website sistem kuis algoritma pemrograman.

\section{Halaman Masuk dan Daftar}


Halaman masuk dan daftar merupakan halaman yang akan pertama ditampilkan saat membuka website sistem kuis algoritma. Seperti yang terlihat pada Gambar 2, halaman ini terdapat form yang digunakan user untuk masuk ataupun mendaftar ke dalam sistem kuis. Pada halaman ini juga tersedia fitur masuk dengan akun Google.
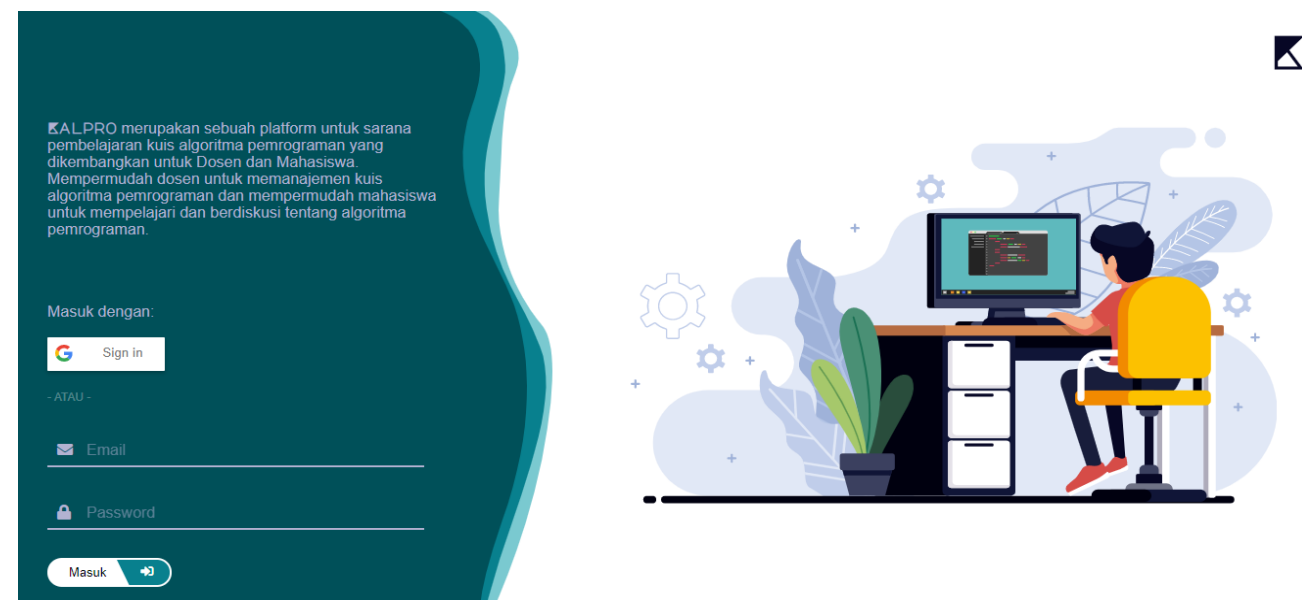

Gambar 2. Halaman masuk dan daftar sistem kuis algoritma pemrograman

\section{Halaman Beranda}

Halaman beranda website ini berisikan logo, bilah navigasi, foto dan nama akun, linimasa diskusi, dan kuis yang akan datang. Seperti yang terlihat pada Gambar 3, pada bagian atas halaman terdapat logo Kalpro atau Kuis Algoritma Pemrograman dan bilah navigasi ke beranda, kelas, dan logout. Pada bagian utama terbagi dalam 3 bagian, di bagian kiri terdapat foto dan nama akun. Pada bagian tengah terdapat linimasa yang terdapat textarea untuk mengirimkan diskusi dan tedapat diskusi beserta komentar yang ada di kelas yang telah diikuti. Pada bagian kanan tedapat kuis yang akan datang dan belum di kerjakan oleh user. Setiap daftar kuis yang ada di bagian kanan berisi informasi judul kuis, waktu kuis dimulai, waktu kuis selesai, dan durasi kuis.

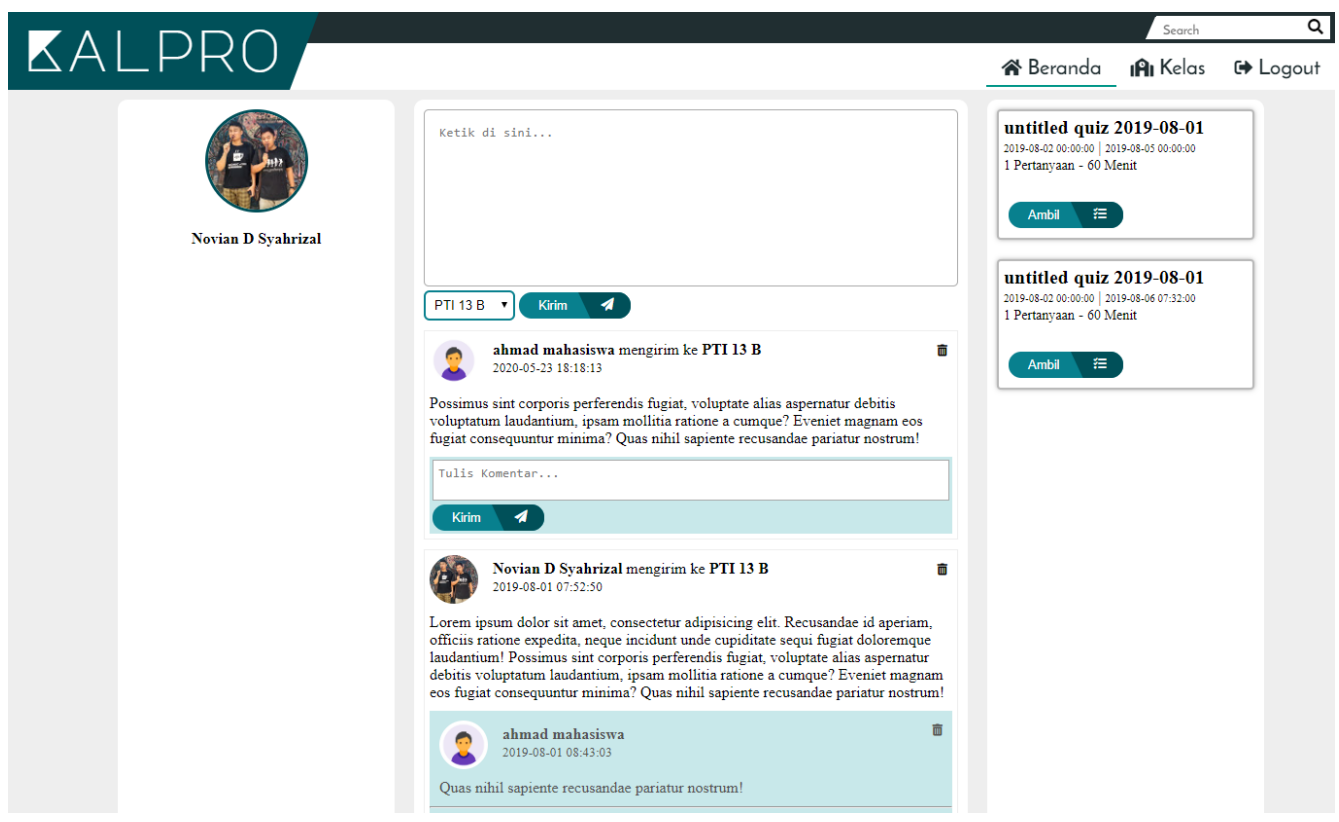

Gambar 3. Halaman beranda sistem kuis algoritma pemrograman 


\section{Halaman Manajemen Kelas}

Halaman manajemen kelas pada website ini berisikan daftar kelas yang telah diikuti oleh user. Seperti yang terlihat pada Gambar 4, halaman manajemen kelas menampilkan daftar kelas yang telah diikuti. Pada setiap daftar kelas terdapat informasi nama kelas, jumlah anggota, dan kode kelas. Pada sebelah kiri terdapat input untuk menambah kelas baru jika akun dosen, dan untuk bergabung ke kelas jika akun mahasiswa.

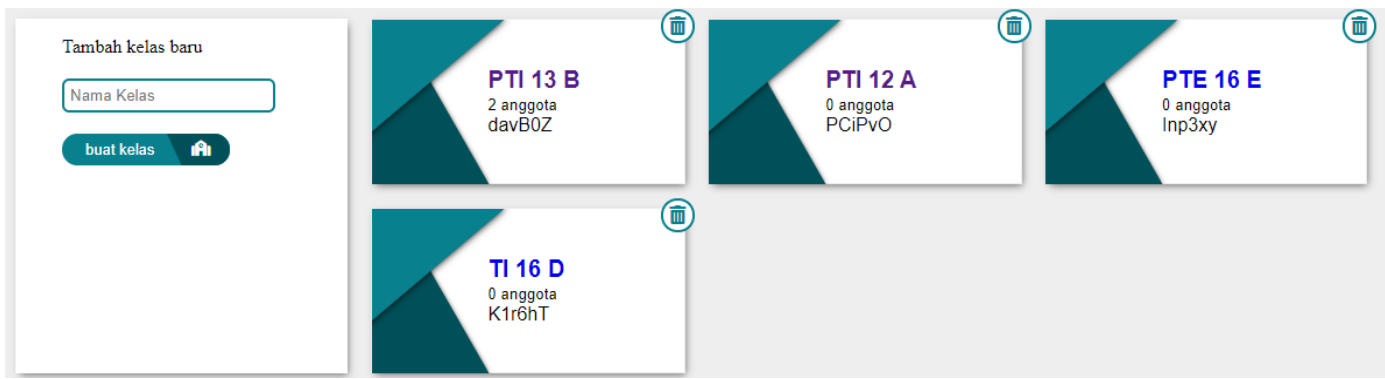

Gambar 4. Halaman manajemen kelas sistem kuis algoritma pemrograman

\section{Halaman Beranda Kelas}

Halaman beranda kelas mirip seperti halaman beranda utama, hanya saja pada halaman beranda kelas pada bagian kiri terdapat menu navigasi yang akan mengubah bagian tengah (Gambar 5). Menu navigasi kiriman berfungsi untuk menampilkan linimasa diskusi, menu navigasi member berfungsi untuk menampilkan daftar anggota yang telah bergabung ke kelas. Sedangkan untuk menu navigasi kuis hanya terdapat pada akun dosen. Menu navigasi kuis menampilkan manajemen kuis untuk menghapus, melihat, mengubah dan menambah kuis dapat dilihat pada Gambar 6 dan 7.

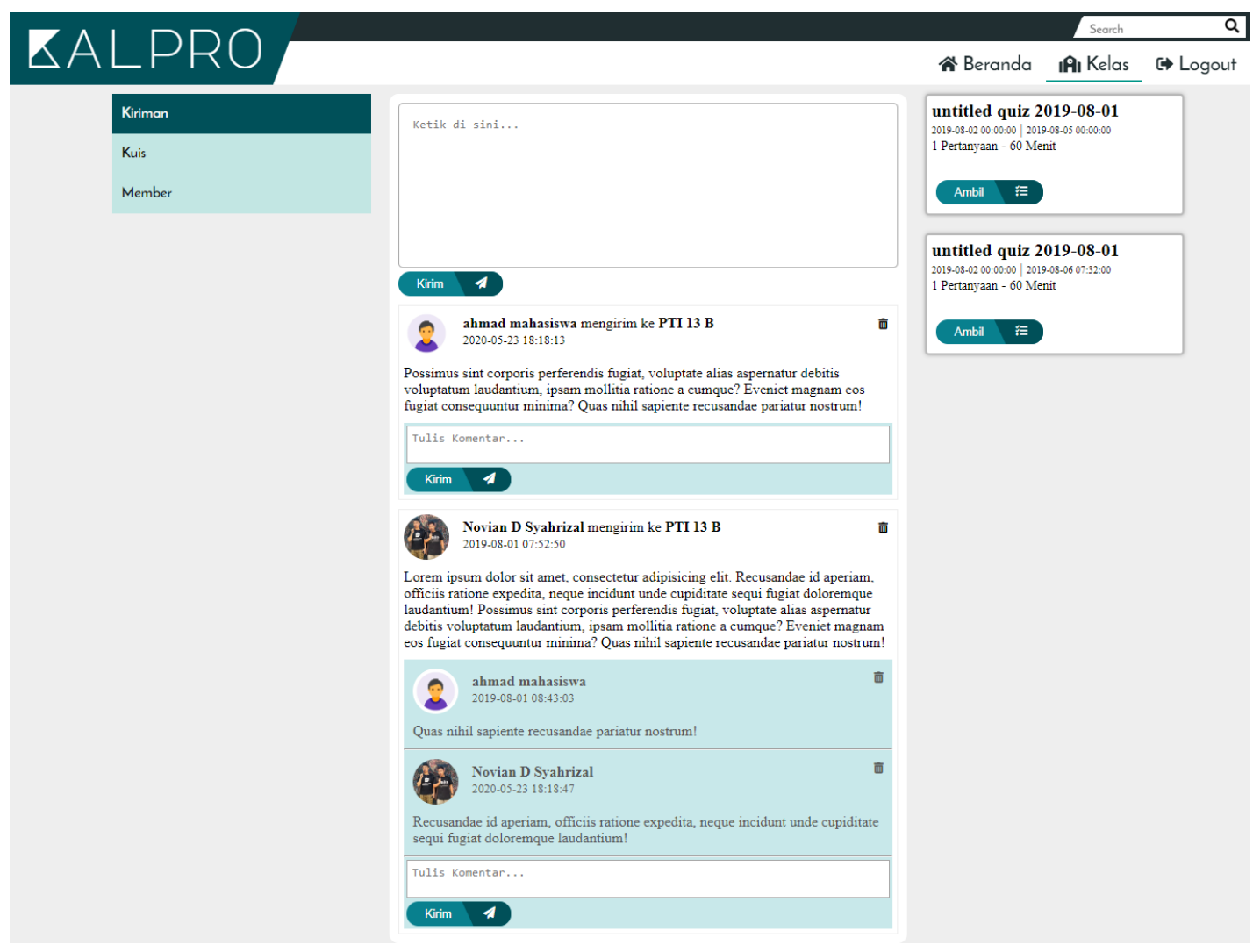

Gambar 5. Halaman beranda kelas sistem kuis algoritma pemrograman 


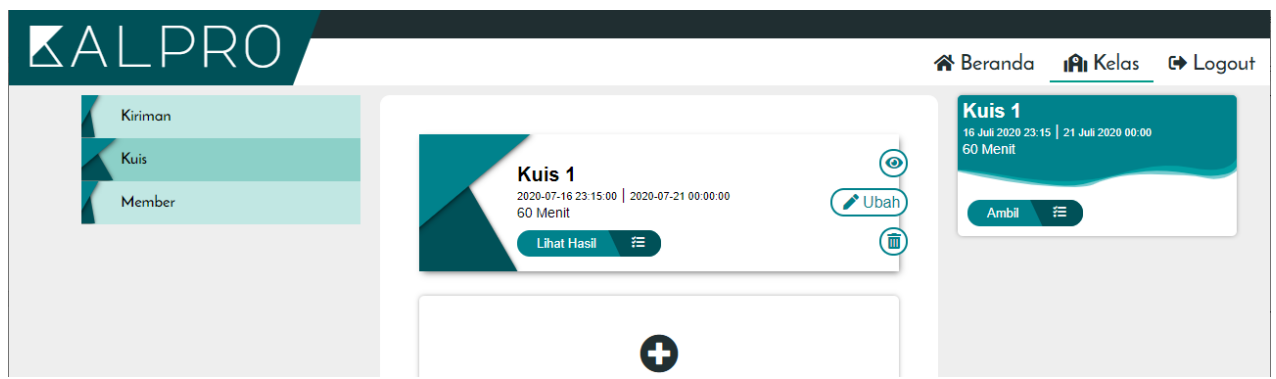

Gambar 6. Halaman daftar kuis sistem kuis algoritma pemrograman

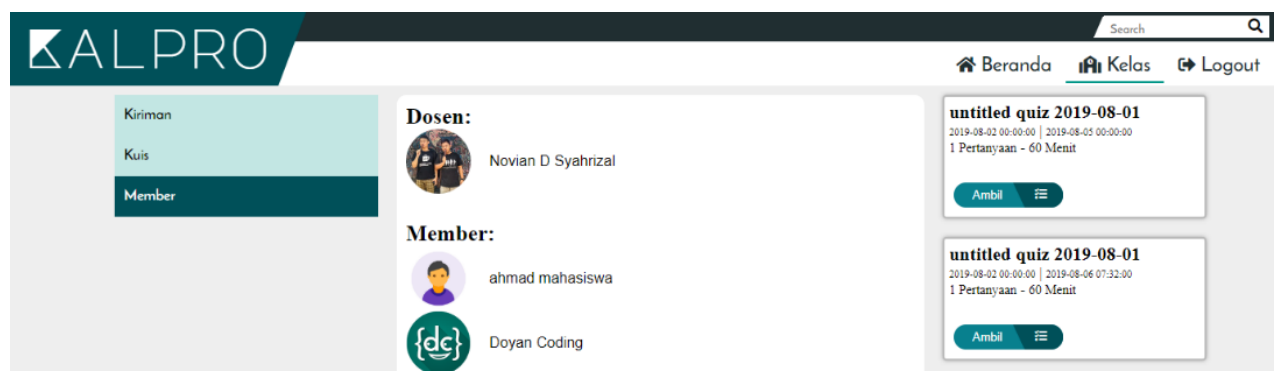

Gambar 7. Halaman daftar anggota kelas sistem kuis algoritma pemrograman

\section{Halaman Tambah Kuis Baru}

Pada halaman tambah kuis baru, user mengisi beberapa input seperti judul kuis, waktu mulai, waktu selesai, durasi, dan pertanyaan. Diagram pada flowchart menggunakan HTML Canvas sehingga ukuran diagram akan menjadi lebih dinamis menyesuaikan dengan teks seperti yang terlihat pada Gambar 8. Sistem drag and drop flowchart menggunakan library Javascript Gojs. Flowchart dari Gojs ketika disimpan berupa data Json, sehingga untuk penilaian benar salahnya flowchart bisa lebih dinamis.

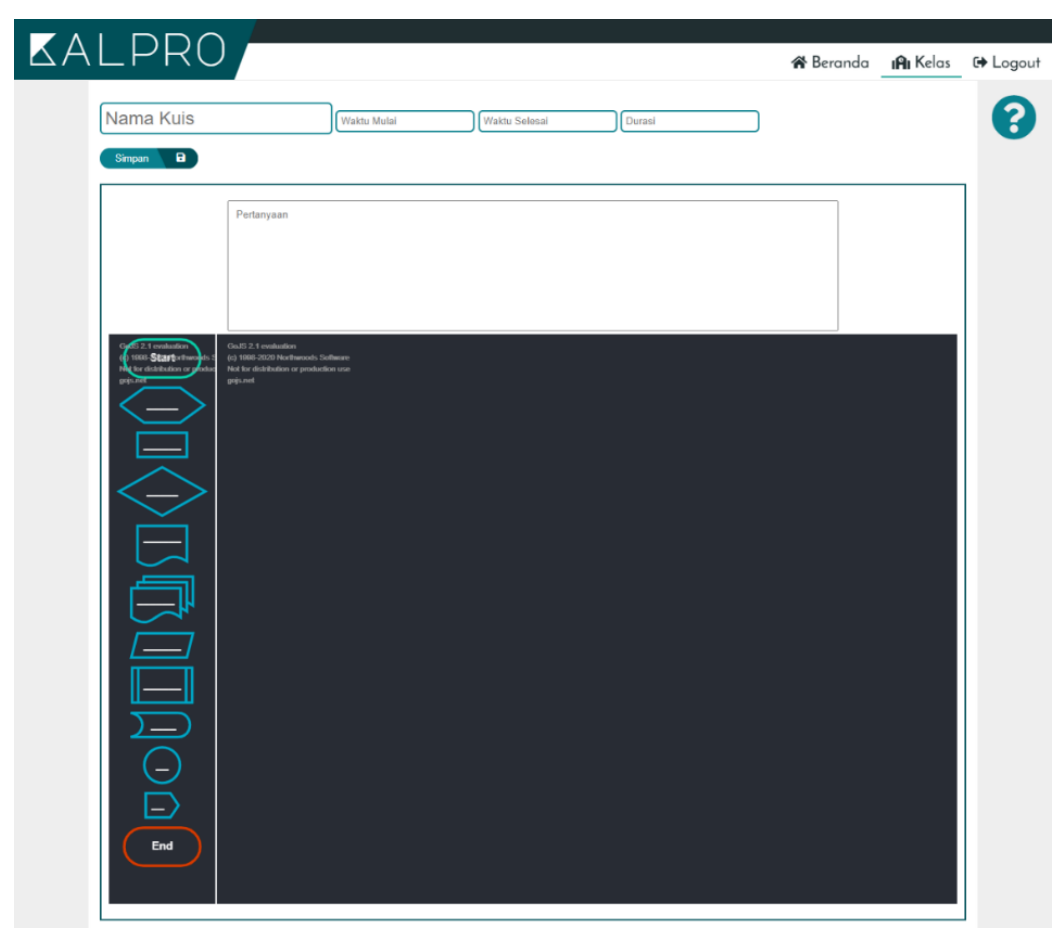

Gambar 8. Halaman tambah kuis baru sistem kuis algoritma pemrograman 


\section{Halaman Jawab Kuis}

Halaman jawab kuis terdapat informasi judul kuis dan sisa durasi, pertanyaan, dan zona drag and drop untuk diagram flowchart. Pada bagian pojok kanan atas dibawah navigation bar terdapat tombol "?" yang akan menampilkan video petunjuk bagaimana cara mengerjakan kuis seperti yang terlihat pada Gambar 9 dan 10

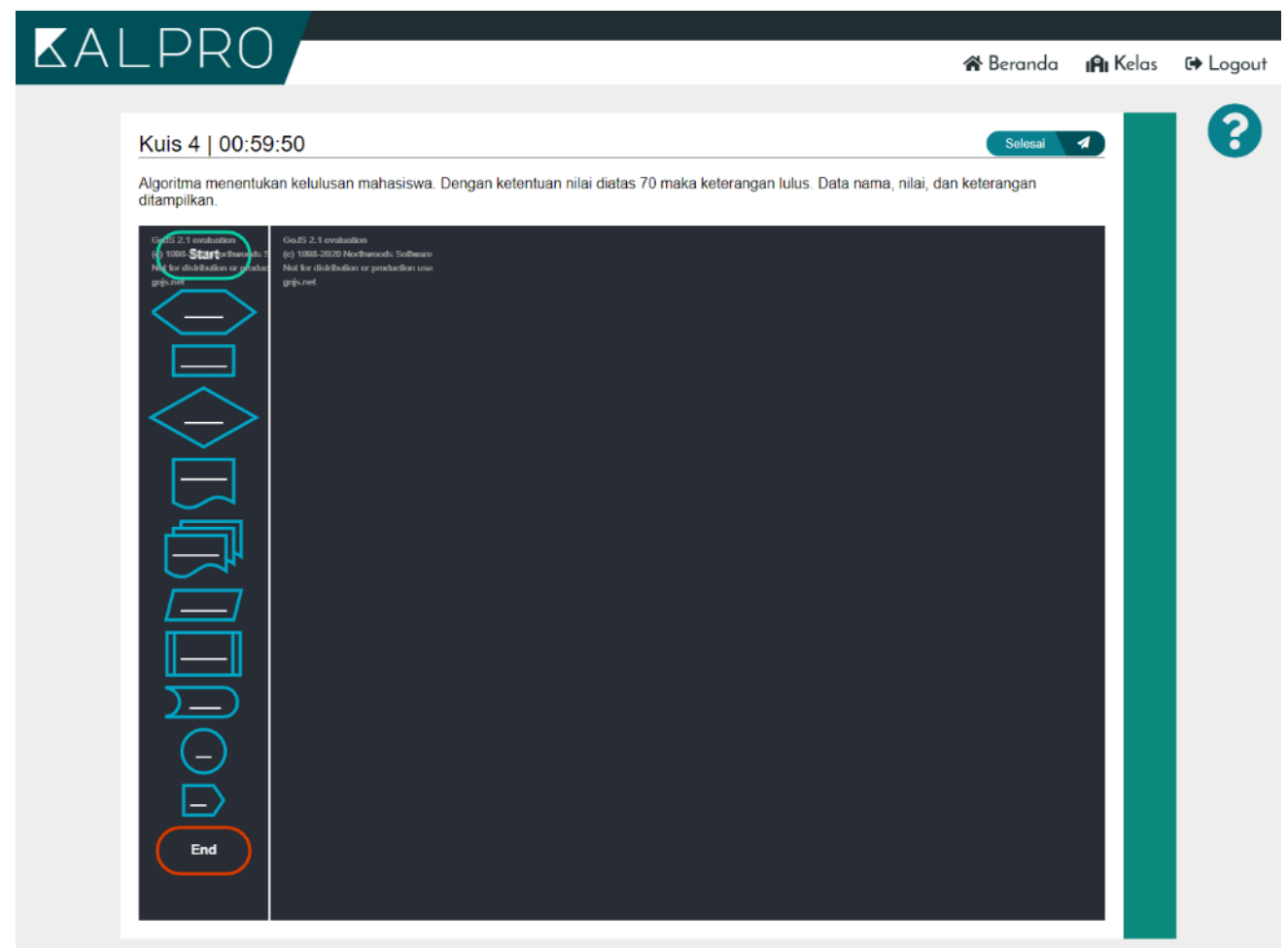

Gambar 9. Halaman mulai jawab kuis sistem kuis algoritma pemrograman

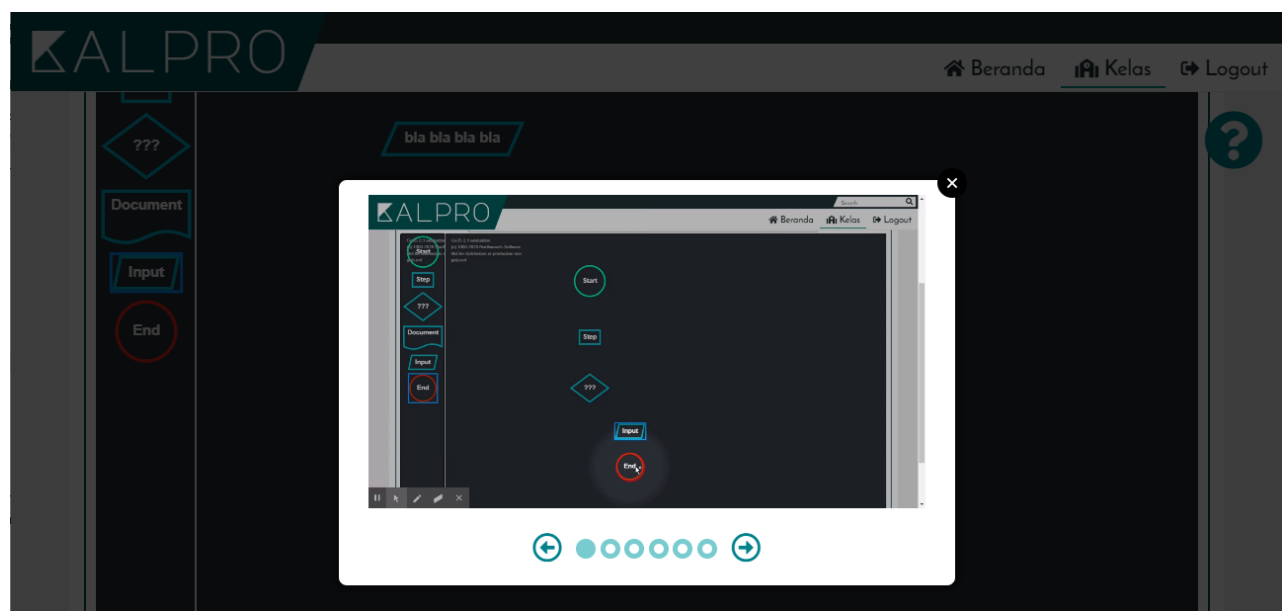

Gambar 10. Pop-up video petunjuk mengerjakan kuis

\section{Halaman Hasil Kuis}

Saat user selesai mengerjakan kuis, sistem kuis akan menampilkan hasil dari kuis yang telah dikerjakan oleh user. Pada halaman hasil kuis, ditampilkan beberapa informasi yaitu judul kuis, waktu mulai, durasi kuis, dan nilai hasil kuis yang telah di kerjakan oleh user dapat dilihat pada Gambar 11. 


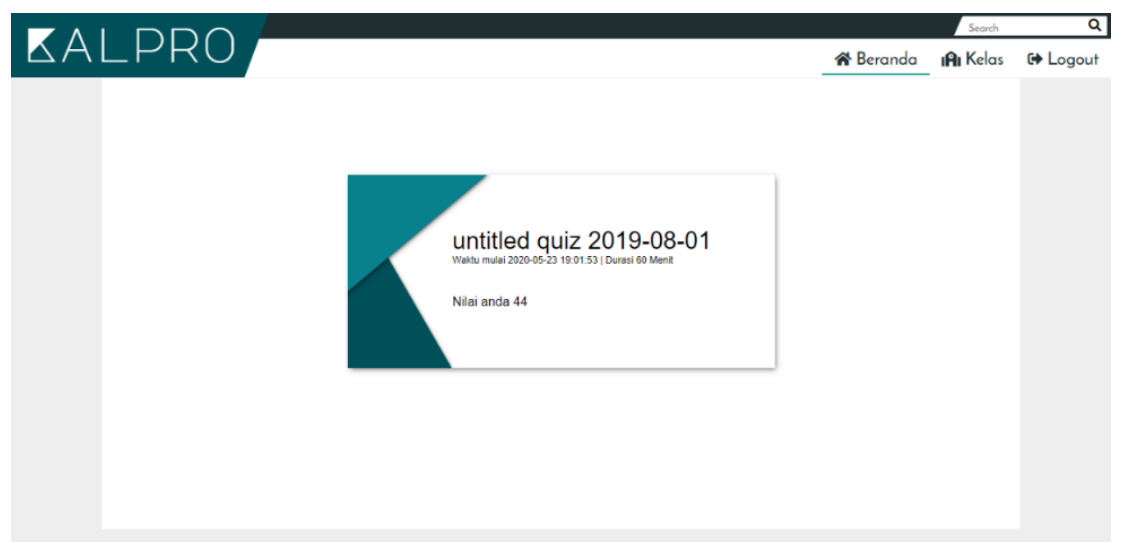

Gambar 11. Halaman hasil kuis sistem kuis algoritma pemrograman

\section{SIMIPULAN}

Berdasarkan pada hasil pengembangan sistem kuis algoritma pemrograman untuk mahasiswa Jurusan Teknik Elektro Universitas Negeri Malang diperoleh kesimpulan sebagai berikut. Sistem kuis algoritma pemrograman berbasis web ini dikembangkan dengan menggunakan bahasa pemrograman PHP dan Javascript. Pada sistem kuis algoritma pemrograman, terdapat fitur utama "drag and drop" untuk memudahkan mahasiswa Teknik Elektro dalam memahami kuis algoritma pemrograman. Terdapat fitur evaluasi untuk dijadikan umpan balik atau "feedback" bagi mahasiswa, serta untuk dijadikan tolak ukur dari keberhasilan proses pembelajaran kuis algoritma pemrograman. Media yang telah dikembangkan ini telah memenuhi kriteria layak, dengan sedikit revisi setelah diadakan validasi media oleh ahli media dengan perolehan data sebesesar $85,29 \%$ dan oleh responden sebesar 82,35\%.Bahan ajar modul ini dapat dikembangkan lebih lanjut terutama dari segi media yang digunakan, agar mahasiswa dapat mencapai hasil belajar yang lebih baik lagi. Selain itu, penelitian terkait penggunaan model urutan kegiatan pembelajaran MPI di dalam kegiatan belajar sesungguhnya perlu dilakukan untuk mengetahui keefektifan model urutan kegiatan pembelajaran MPI dalam meningkatkan hasil belajar mahasiswa.

Sistem kuis algoritma pemrograman ini dapat dikembangkan lebih lanjut terutama pada bagian kuis, agar mahasiswa lebih tertarik bisa dengan menambahkan beberapa variasu kuis seperti pilihan ganda dan fill in the blank. Selain itu, untuk proses evaluasi pada sistem kuis algoritma pemrograman lebih efektif dilakukan secara manual dari pada dilakukan secara otomatis oleh sistem, dikarenakan jika proses evaluasi hanya dengan mencocokkan flowchart yang dikerjakan mahasiswa dengan dosen hanya akan mematikan kreatifitas mahasiswa.

\section{DAFTAR RUJUKAN}

Isroqmi, A. (2017). Kemampuan Mahasiswa Memahami Logika Pemrograman Komputer Melalui Algoritma. Nabla Dewantara: Jurnal Pendidikan Matematika, 2(2), 59-74.

Nasution, S. D. (2013). Perancangan aplikasi kompresi file teks dengan menerapkan Algoritma Goldbach Codes. J. Ilm. INFOTEK, 1(1), 104-109.

Nuraini, R. (2015). Desain algorithma operasi perkalian matriks menggunakan metode flowchart. Jurnal Teknik Komputer, $1(1), 144-151$

Patmanthara, S. (2016). P. B. K. T. dan K. (2016). Pembelajaran berbantuan komputer. Teknologi Dan Kejuruan: Jurnal Teknologi, Kejuruan Dan Pengajarannya, 1(1), 13-21.

Purnomo, B. H. (2011). Metode dan teknik pengumpulan data dalam Penelitian Tindakan Kelas (Classroomaction Research). Jurnal Pengembangan Pendidikan, 8(1), 210251.

Santoso, S., \& Nurmalina, R. (2017). Perencanaan dan pengembangan aplikasi absensi mahasiswa menggunakan Smart Card guna pengembangan kampus cerdas. Jurnal Integrasi, 9(1), 84-91.

Sembiring, M. A., Sibuea, M. F. L., \& Sapta, A. (2018). Analisa kinerja Algoritma C. 45 dalam memprediksi hasil belajar. Journal Of Science and Social Research, 1(1), 73-79.

Sismoro, H. (2005). Pengantar logika informatika. Algoritma dan pemrograman komputer. Penerbit Andi.

Sitorus, L. (2015). Algoritma dan pemrograman. Penerbit Andi. 
Sukarsa, I. M. (2019). Aplikasi konversi flowchart ke kode program bahasa pemrograman Pl/Sql Mysql. Majalah Ilmiah Teknologi Elektro, 8(2).

Trianto, T. (2010). Mendesain model pembelajaran inovatif progresif. Kencana Prenada Group.

Ula, S. S. (2013). Revolusi belajar: Optimalisasi kecerdasan melalui pembelajaran berbasis kecerdasan majemuk. Yogyakarta: Ar-Ruzz Media.

Wijayanti, S., \& Sungkono, J. (2017). Pengembangan perangkat pembelajaran mengacu Model Creative Problem Solving berbasis somatic, auditory, visualization, intellectually. Al-Jabar: Jurnal Pendidikan Matematika, 8(2), 101-110. 